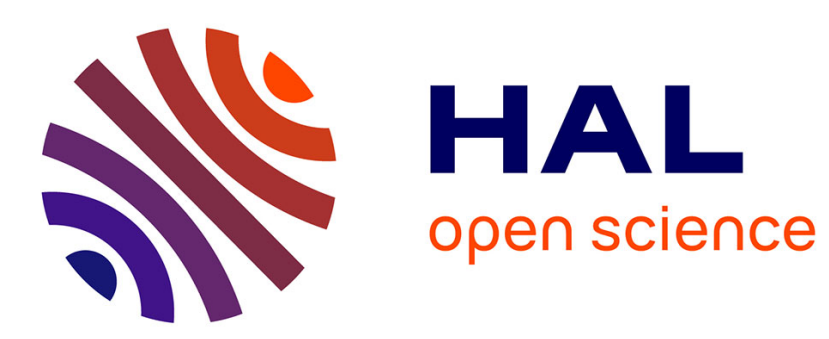

\title{
Extrinsic factors modifying expressivity of the variant C282Y, H63D, S65C phenotypes in 1,294 Danish men \\ Palle Pedersen, Nils Milman
}

\section{To cite this version:}

Palle Pedersen, Nils Milman. Extrinsic factors modifying expressivity of the variant C282Y, H63D, S65C phenotypes in 1,294 Danish men. Annals of Hematology, 2009, 88 (10), pp.957-965. 10.1007/s00277-009-0714-x . hal-00535040

\author{
HAL Id: hal-00535040 \\ https://hal.science/hal-00535040
}

Submitted on 11 Nov 2010

HAL is a multi-disciplinary open access archive for the deposit and dissemination of scientific research documents, whether they are published or not. The documents may come from teaching and research institutions in France or abroad, or from public or private research centers.
L'archive ouverte pluridisciplinaire HAL, est destinée au dépôt et à la diffusion de documents scientifiques de niveau recherche, publiés ou non, émanant des établissements d'enseignement et de recherche français ou étrangers, des laboratoires publics ou privés. 


\title{
Extrinsic factors modifying expressivity of the $\mathrm{HFE}$ variant C282Y, H63D, S65C phenotypes in 1,294 Danish men
}

\author{
Palle Pedersen • Nils Milman
}

Received: 26 January 2009 / Accepted: 13 February 2009 / Published online: 7 March 2009

(C) Springer-Verlag 2009

\begin{abstract}
This study analysed the influence of extrinsic factors on the phenotypic expression of $H F E$ gene variants in ethnic Danish men. A cohort of 6,020 men aged 30-53 years was screened for HFE C282Y, H63D and S65C variants. Serum iron, serum transferrin, transferrin saturation, and serum ferritin were analysed in 1,452 men and 1,294 men completed a questionnaire on factors, which could influence iron balance. The $\mathrm{C} 282 \mathrm{Y}$ allele was present in $5.6 \%, \mathrm{H} 63 \mathrm{D}$ in $12.8 \%$ and $\mathrm{S} 65 \mathrm{C}$ in $1.8 \%$ of the men. In the entire series, $3 \%$ had elevated iron status markers (transferrin saturation $\geq 50 \%$, ferritin $\geq 300 \mu \mathrm{g} / \mathrm{L}$ ). Selfreported liver disease had an elevating effect and peptic ulcer a lowering effect on iron status markers. Age increased the fraction of men with elevated ferritin from $8.3 \%$ at $32-38$ years to $16.2 \%$ at $46-53$ years of age $(p=0.002)$. Blood donation had a lowering effect on iron status markers $(p=0.0001)$. Alcohol consumption elevated serum iron and serum ferritin $(p=0.001)$. Meat consumption had an elevating effect $(p=0.02)$ and milk consumption a lowering effect $(p=0.03)$ on serum ferritin. There was no influence of vitamin-mineral tablets on iron status markers. In adjusted logistic regression analysis, the $H F E$ genotype had the highest impact on iron status markers; high alcohol consumption was significantly associated with elevated transferrin saturation. High age and high alcohol consumption were significantly associated with elevated ferritin and high egg consumption and blood donation was significantly associated with normal ferritin levels. In conclusion, the expressivity of HFE variant phenotypes in Danish men was
\end{abstract}

P. Pedersen $\cdot$ N. Milman $(\bowtie)$ Department of Clinical Biochemistry, Næstved Hospital, University of Copenhagen, DK-4700 Næstved, Denmark e-mail: nils.mil@dadlnet.dk enhanced by alcohol and meat consumption and decreased by milk and egg consumption and blood donation.

Keywords Expressivity - Genotypes · Hemochromatosis · Mutations $\cdot$ Penetrance $\cdot$ Scandinavia

Genetic HFE hemochromatosis is inherited as an autosomal recessive trait [1-3] and the phenotypic penetrance of the most important HFE mutation or variant, i.e. C282Y, has been assessed in various studies using phenotypic, clinical and genetic criteria [4-11]. A longitudinal study of $\mathrm{C} 282 \mathrm{Y}$ homozygous individuals, followed up for more than 10 years, assessed the fraction, who developed disease due to iron overload [12].

The expressivity of the HFE variant C282Y (c845 $\mathrm{G} \rightarrow \mathrm{A}), \mathrm{H} 63 \mathrm{D} \quad(\mathrm{c} 187 \mathrm{C} \rightarrow \mathrm{G})$ and $\mathrm{S} 65 \mathrm{C} \quad(\mathrm{c} 193 \mathrm{~A} \rightarrow \mathrm{T})$ phenotypes also depend on extrinsic factors or modifiers of iron balance, such as dietary iron intake, bioavailabilty of dietary iron, blood losses at menstruation and pregnancy as well as blood donation. The aim of the present study was to analyse environmental extrinsic factors, which might influence the phenotypic expression of the $H F E$ variants on iron status markers.

\section{Methods}

Participants and study design

The study was performed in 2000-2001 and described in previous papers [11, 13, 14]. It was approved by The Danish Scientific Ethical Committee and fulfilled The Declaration of Helsinki. Ethnic Danish men aged 30-53 years $(n=10,993)$ living in Næstved and Vordingborg municipalities were drawn from the Census Registry and invited to participate. 
Table 1 Data in 1,294 men having iron status markers analysed

\begin{tabular}{lllll}
\hline & Yes (n) & No (n) & Total (n) & No data (n) \\
\hline Fasting blood sample & 1,202 & 250 & 1,452 & 1 \\
Blood donation & 448 & 837 & 1,285 & 168 \\
Self-reported disease & & & & \\
$\quad$ Diabetes & 28 & 1,266 & 1,294 & 159 \\
Arthritis & 82 & 1,212 & 1,294 & 159 \\
Liver disease & 15 & 1,279 & 1,294 & 159 \\
Anemia & 17 & 1,277 & 1,294 & 159 \\
Iron deficiency & 20 & 1,274 & 1,294 & 159 \\
Hemochromatosis & 3 & 1,291 & 1,294 & 159 \\
Peptic ulcer & 57 & 1,237 & 1,294 & 159 \\
Heart disease & 32 & 1,262 & 1,294 & 210 \\
Iron intake & & & & 553 \\
Vitamin-mineral tablets & 401 & 842 & 1,243 & 900 \\
Iron tablets & 29 & 871 & & \\
\hline
\end{tabular}

In the first phase of the study, HFE genotypes were assessed on saliva samples from the participants. In the second phase, participants with $H F E$ variants plus participants in whom the genotype could not be assessed on saliva, were invited to genetic retesting and analysis of iron status markers. Participants with elevated iron status markers were invited to a reanalysis.

\section{Iron status}

Blood samples were drawn in the fasting state (except in 250 men) between 0800 and 1000 hours. Analyses of iron status markers, i.e. serum iron, serum transferrin and serum ferritin were performed on Dimension ${ }^{\circledR}$ RxL Clinical Chemistry System with heterogeneous Immunoassay Module (Dade Behring Inc., Deerfield, Illinois, USA, now merged with Siemens Healthcare Diagnostics GmbH, Eschborn, Germany) [11]. The serum transferrin saturation percent (TSAT) was calculated from serum iron and serum transferrin concentrations as: serum iron $(\mu \mathrm{mol} / \mathrm{L}) \times 100 /$ serum transferrin $(\mu \mathrm{mol} / \mathrm{L}) \times 2$. Transferrin saturation values $\geq 50 \%$

Table 2 Iron status markers in the study population, median $(95 \%$ interval)

\begin{tabular}{lllll}
\hline & $\begin{array}{l}\text { All } \\
\mathrm{n}=1452\end{array}$ & $\begin{array}{l}\text { Fasting } \\
1202\end{array}$ & $\begin{array}{l}\text { Non-fasting } \\
250\end{array}$ & P-value* \\
\hline Ferritin $(\mu \mathrm{g} / \mathrm{L})$ & 153 & 153 & 152 & 1.0 \\
& $(25-531)$ & $\begin{array}{l}(23-527) \\
(31-681)\end{array}$ & \\
Transferrin $(\mu \mathrm{mol} / \mathrm{L})$ & $29(22-40)$ & $30(22-40)$ & $29(23-39)$ & 0.3 \\
Iron $(\mu \mathrm{mol} / \mathrm{L})$ & $18(8-33)$ & $17(8-33)$ & $19(9-36)$ & 0.006 \\
TSAT $(\%)$ & $29(12-63)$ & $29(12-62)$ & $32(13-82)$ & 0.003 \\
\hline
\end{tabular}

*) Mann-Whitney's test between fasting and non-fasting men and serum ferritin values $\geq 300 \mu \mathrm{g} / \mathrm{L}$ were considered elevated $[15,16]$.

\section{Questionnaire}

The questionnaire yielded information concerning factors, which might influence iron status, such as blood donation, iron supplements, self-reported disease, alcohol consumption and dietary habits comprising consumption of meat, milk and egg. As previously reported [13], the questionnaire also assessed the psychological consequences of genetic screening.

\section{Statistics}

Statistical analyses were performed using Statistical Package for the Social Sciences 11.5.1 for Windows. Non-parametric statistics were used for comparison between groups (Kruskall Wallis'test, Mann-Whitney's test, Pearson's $\chi^{2}$ test). The $95 \%$

Table 3 Influence of age on iron status markers, median (95\% interval)

\begin{tabular}{llllll}
\hline Age (y) & $\mathrm{n}^{\mathrm{a}}$ & $\begin{array}{l}\text { Ferritin } \\
(\mu \mathrm{g} / \mathrm{L})\end{array}$ & $\begin{array}{l}\text { Ferritin } \\
\geq 300 \mu \mathrm{g} / \mathrm{L}(\%)\end{array}$ & $\mathrm{n}^{\mathrm{b}}$ & TSAT (\%) \\
\hline $32-39$ & 363 & $149(25-417)$ & 8.3 & 327 & $30(13-68)$ \\
$40-46$ & 433 & $153(25-519)$ & 13.9 & 301 & $29(12-59)$ \\
$47-53$ & 656 & $153(23-566)$ & 16.2 & 574 & $28(12-61)$ \\
P-value & & $0.09^{*}$ & $0.002^{* *}$ & & $0.07 *$ \\
\hline
\end{tabular}

a) The 3 groups had similar HFE genotype distribution, $\chi^{2}$ test, $p=0.3$

b) Fasting men

*) Kruskal Wallis' test

**) $\chi^{2}$ test 
Table 4 Influence of alcohol consumption on iron status markers, median values

\begin{tabular}{lllllll}
\hline $\begin{array}{l}\text { Drinks } \\
\text { week }\end{array}$ & $\mathrm{n}^{\mathrm{b}}$ & $\begin{array}{l}\text { Ferritin } \\
(\mu \mathrm{g} / \mathrm{L})\end{array}$ & $\begin{array}{l}\text { Transferrin } \\
(\mu \mathrm{mol} / \mathrm{L})\end{array}$ & $\mathrm{n}^{\mathrm{c}}$ & $\begin{array}{l}\text { Iron } \\
(\mu \mathrm{mol} / \mathrm{L})\end{array}$ & $\begin{array}{l}\text { TSAT } \\
(\%)\end{array}$ \\
\hline$<5$ & 586 & 145 & 29 & 500 & 17 & 29 \\
$5-15$ & 481 & 149 & 30 & 404 & 18 & 30 \\
$16-21$ & 144 & 156 & 30 & 109 & 17 & 28 \\
$>21$ & 70 & 225 & 31 & 45 & 20 & 32 \\
P-value* & 0.0001 & 0.2 & & 0.01 & 0.3 \\
\hline
\end{tabular}

a) One drink $=12 \mathrm{~g}$ ethanol

b) The 4 groups had similar HFE genotype distribution, $\chi^{2}$ test $p=0.2$

c) Fasting men

*) Kruskal-Wallis' test

reference interval was defined as the 2.5-97.5 interpercentile range. The significance level was set at 0.05 .

The association between $H F E$ genotype and the risk of having elevated transferrin saturation and/or serum ferritin was assessed by conditional logistic regression with adjusted odds ratios (OR) and 95\% confidence intervals (CI). HFE genotype, age, blood donation, self-reported disease, vitamin mineral tablets containing iron, alcohol, meat, milk and egg consumption were included as covariates.

The predicted phenotypic penetrance of the HFE genotypes, adjusted for other covariates, was calculated as previously described [11]. The probability for a specific $H F E$ genotype to present elevated transferrin saturation or elevated serum ferritin is an estimate of penetrance when other modifiers are in the reference state. The reference group was wt/wt homozygous men aged 32-39 years, who never had donated blood, had no self-reported disease and low alcohol, meat, milk and egg consumption.

\section{Results}

Salvia samples were obtained from 6,567/10,993 (60\%) men. In 1,064/6,567 (16\%) men, genotype could not be assessed. They were invited to genetic testing and analysis of iron status markers, which was obtained in 522/1,064 (49\%).
HFE genotype was assessed in 6,020 men. The 2,149 men carrying a $H F E$ variant were invited to analysis of iron status markers being obtained in 930/2,149 (43\%) men. In the entire series, iron status markers were obtained in 1,452/ $6,020(24 \%)$ men of whom 1,294/1,452 (89\%) completed the questionnaire. Data from the questionnaire are summarized in Table 1.

$H F E$ allele frequencies

The HFE genotypes $\mathrm{C} 282, \mathrm{H} 63$, and $\mathrm{S} 65$ are designated wild type (wt). In the entire series, the allele frequency of C282Y, H63D, and S65C variants was $5.6 \%, 12.8 \%$ and $1.8 \%$, respectively $[11,14]$.

Iron status markers

In total 250/1,452 (17\%) men were non-fasting. Serum iron and transferrin saturation was significantly lower in fasting than in non-fasting men (Table 2). Consequently, we used only serum iron values in fasting men in the calculation of transferrin saturation and the statistical analyses.

Age vs iron status markers

Age had no influence on transferrin saturation values. There was no significant difference in serum ferritin levels in the various age groups (Table 3) and the lower limit of the $95 \%$ reference interval for ferritin remained unchanged from 32 to 53 years of age. However, the upper limit for ferritin and the percentage of men having elevated ferritin $\geq 300 \mu \mathrm{g} / \mathrm{L}$ increased gradually with age.

Alcohol vs iron status markers

There was a significant elevation of serum ferritin and serum iron with increasing alcohol consumption (Table 4).

Blood donation vs iron status markers

In blood donors, serum ferritin, serum iron and transferrin saturation decreased and serum transferrin increased with the number of blood donations (Table 5 and Fig. 1).
Table 5 Influence of blood donation on iron status markers, median values
a) The 4 groups had similar
HFE genotype distribution,
$\chi^{2}$ test $\mathrm{p}=0.3$
b) Fasting men
*) Kruskal-Wallis' test

\begin{tabular}{lccllll}
\hline Blood donor & $\mathrm{n}^{\mathrm{a}}$ & Ferritin $(\mu \mathrm{g} / \mathrm{L})$ & Transferrin $(\mu \mathrm{mol} / \mathrm{L})$ & $\mathrm{n}^{\mathrm{b}}$ & Iron $(\mu \mathrm{mol} / \mathrm{L})$ & TSAT $(\%)$ \\
\hline No & 856 & 179 & 29 & 707 & 18 & 30 \\
\multicolumn{2}{l}{ Yes (donation last 2} & years $)$ & & & & \\
0 & 153 & 154 & 29 & 130 & 17 & 29 \\
$1-4$ & 131 & 93 & 31 & 112 & 18 & 29 \\
$>4$ & 133 & 44 & 32 & 103 & 15 & 23 \\
P-value* & & 0.0001 & 0.0001 & & 0.01 & 0.0001 \\
\hline
\end{tabular}



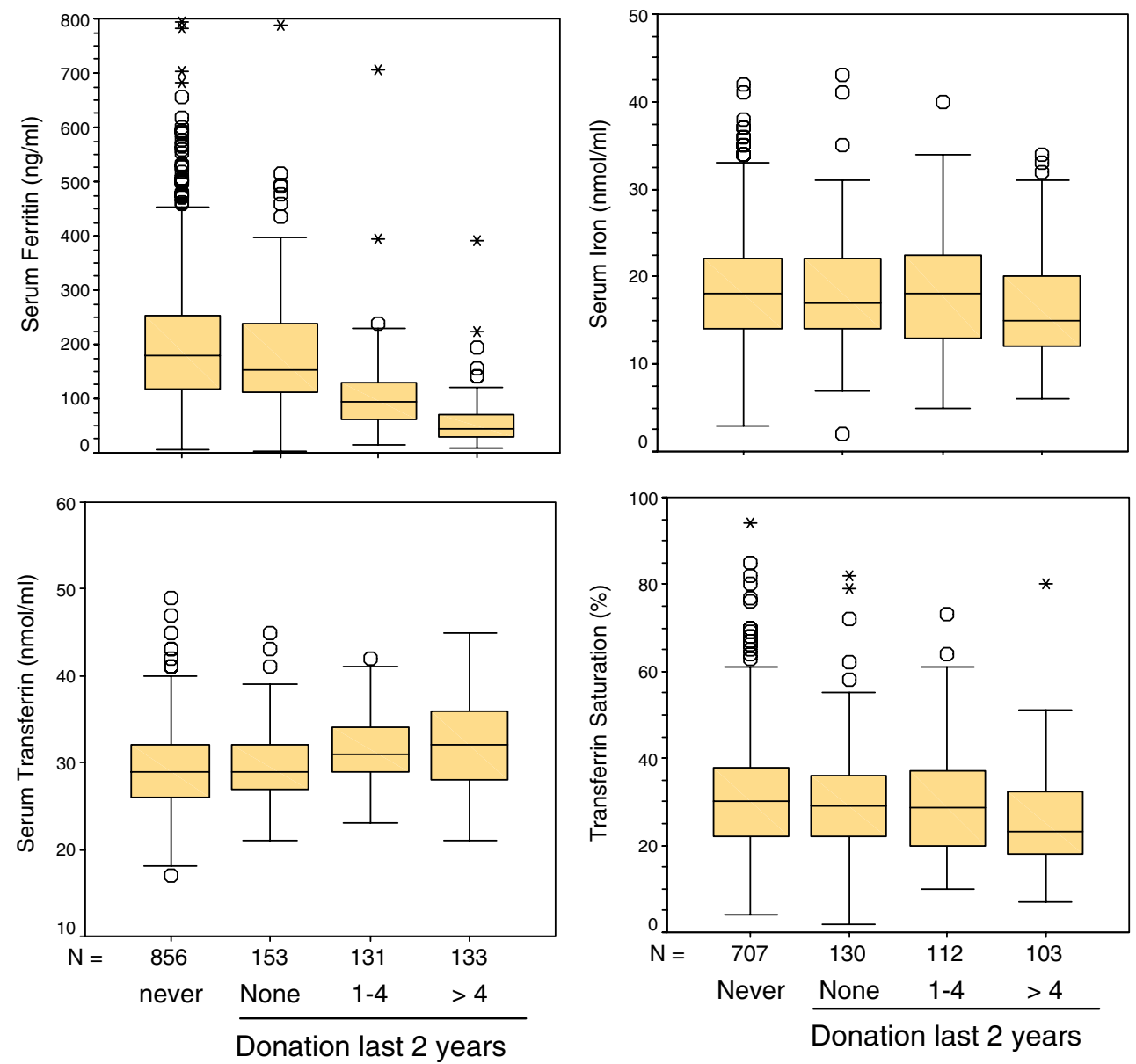

Fig. 1 Influence of blood donation on iron status markers

Blood donors who were bled more than two years ago had significantly lower median ferritin than non-donors (Mann-Whitney's test, $\mathrm{p}=0.04$ ), but similar serum iron, serum transferrin and transferrin saturation.

Donors bled from one up to more than four times during the last two years had higher serum transferrin than donors who were bled more than two years ago and non-donors (Mann-Whitney's test, $\mathrm{p}<0.001$ ). Donors bled more than 4 times during the last two years had lower serum iron and transferrin saturation than non-donors $(\mathrm{p}=0.01$ and $\mathrm{p}=$ 0.0001 , respectively).

Dietary factors vs iron status markers

Consumption of meat had an elevating effect and consumption of milk a lowering effect on serum ferritin levels (Table 6). There was no significant influence of egg consumption and vitamin-mineral tablets containing iron. A few took oral iron, they had low iron status due to iron deficiency, which obviously was the indication for treatment.
Self-reported disease vs iron status markers

Self-reported disease had a significant influence on transferrin saturation (Table 7). Although median serum ferritin level was higher in men with liver disease and lower in men with peptic ulcer, the differences were not statistically significant, probably due to the low number of men in the groups.

Logistic regression analysis

C282Y homozygotes had an 86-fold higher risk of elevated ferritin and a 66-fold higher risk of elevated transferrin saturation than wt/wt homozygotes (Tables 8 and 9). C282Y/H63D compound heterozygotes had a 7.2-fold higher risk of having elevated transferrin saturation and a 3.3-fold higher risk of having elevated ferritin than wt/wt homozygotes. Of the remaining genotypes, C282Y heterozygotes and H63D homozygotes had higher risk of having elevated transferrin saturation. 
Table 6 Influence of dietary factors on iron status markers, median values

\footnotetext{
a) Fasting men

*) Mann-Whitney's test

**) Kruskal-Wallis' test
}

\begin{tabular}{|c|c|c|c|c|c|c|}
\hline & $\mathrm{n}$ & Ferritin $(\mu \mathrm{g} / \mathrm{L})$ & Transferrin $(\mu \mathrm{mol} / \mathrm{L})$ & $\mathrm{n}^{\mathrm{a}}$ & Iron $(\mu \mathrm{mol} / \mathrm{L})$ & TSAT $(\%)$ \\
\hline \multicolumn{7}{|c|}{ Meat (days/week) } \\
\hline$<4$ & 188 & 132 & 30 & 151 & 17 & 27 \\
\hline $4-6$ & 549 & 156 & 30 & 461 & 17 & 28 \\
\hline 7 & 503 & 153 & 29 & 414 & 18 & 30 \\
\hline P-value** & & 0.02 & 0.3 & & 0.14 & 0.16 \\
\hline \multicolumn{7}{|c|}{ Milk (days/week) } \\
\hline$<4$ & 233 & 167 & 30 & 189 & 17 & 27 \\
\hline $4-6$ & 189 & 151 & 30 & 156 & 17 & 27 \\
\hline Daily & 850 & 147 & 29 & 705 & 17 & 29 \\
\hline $\mathrm{P}$-value** & & 0.03 & 0.5 & & 0.7 & 0.3 \\
\hline \multicolumn{7}{|c|}{ Egg (no./week) } \\
\hline $0-4$ & 1124 & 153 & 29 & 930 & 17 & 29 \\
\hline$>4$ & 150 & 144 & 30 & 121 & 18 & 30 \\
\hline P-value* & & 0.3 & 0.4 & & 0.8 & 0.7 \\
\hline \multicolumn{7}{|c|}{$\begin{array}{l}\text { Vitamin-mineral } \\
\text { tablets }\end{array}$} \\
\hline No & 842 & 154 & 30 & 699 & 18 & 29 \\
\hline Yes & 401 & 142 & 29 & 329 & 17 & 28 \\
\hline P-value* & & 0.08 & 0.12 & & 0.01 & 0.06 \\
\hline \multicolumn{7}{|c|}{ Iron tablets } \\
\hline No & 870 & 151 & 29 & 717 & 17 & 28 \\
\hline Yes & 29 & 62 & 30 & 22 & 12 & 22 \\
\hline P-value* & & 0.0001 & 0.3 & & 0.03 & 0.02 \\
\hline
\end{tabular}

High alcohol consumption was associated with elevated transferrin saturation. High age and high alcohol consumption were significantly associated with elevated ferritin and high egg consumption and blood donation was significantly associated with normal ferritin levels.

\section{Discussion}

In genetic terms, penetrance describes the proportion of individuals carrying a particular variation of a gene, i.e. the genotype that expresses an associated trait, i.e. the

Table 7 Self-reported disease and iron status markers in Danish men, median values

\begin{tabular}{clllllll}
\hline Disease & & $\mathrm{n}$ & $\begin{array}{l}\text { Ferritin } \\
(\mu \mathrm{g} / \mathrm{L})\end{array}$ & $\begin{array}{l}\text { Transferrin } \\
(\mu \mathrm{mol} / \mathrm{L})\end{array}$ & $\mathrm{n}^{\mathrm{a}}$ & $\begin{array}{l}\text { Iron } \\
(\mu \mathrm{mol} / \mathrm{L})\end{array}$ & $\begin{array}{l}\text { TSAT } \\
(\%)\end{array}$ \\
\hline $\begin{array}{c}\text { Liver } \\
\text { disease }\end{array}$ & no & 1268 & 151 & 30 & 1048 & 17 & 29 \\
Peptic & 15 & 202 & 28 & 12 & 21 & $36^{*}$ \\
ulcer & no & 1226 & 153 & 29 & 1011 & 18 & 29 \\
& yes & 57 & 125 & 30 & 49 & $16^{*}$ & $26^{*}$ \\
\hline
\end{tabular}

a) Fasting men

Mann-Whitney's test: * $\mathrm{p}<0.05 * * \mathrm{p}<0.001$ compared with the "no" groups phenotype, while expressivity refers to variations of a phenotype in individuals carrying a particular genotype. The present study assessed the penetrance of the three most frequent $H F E$ variants, i.e. the influence of the genotype on the phenotype, as well as the impact of age and environmental factors on the expressivity of the phenotype. Men are more predisposed to iron overload than women, i.e. the influence of the $H F E$ variants and modifying factors are more likely to be expressed in men than in women [1, 12]. Due to iron losses at menstruation and pregnancy, iron overload is less frequent in fertile women [17]. Allen et al. [12] followed up $203 \mathrm{C} 282 \mathrm{Y}$ homozygous individuals over 12 years; $28 \%$ of men vs $1 \%$ of women developed iron overload-related disease.

In our series, the phenotypic penetrance in $\mathrm{C} 282 \mathrm{Y}$ homozygous men $(n=23)$ was close to $100 \%$ and higher than the penetrance in $\mathrm{C} 282 \mathrm{Y} / \mathrm{H} 63 \mathrm{D}$ compound heterozygous [11].

$H F E$ variant homozygous and compound heterozygous men had significantly higher transferrin saturation than wt/wt homozygous men [11]. However, even among the wt/wt homozygotes, $6 \%$ had elevated transferrin saturation, $13 \%$ elevated serum ferritin and $1 \%$ elevation of both iron status markers [11], suggesting that other genetic factors (besides $H F E$ ) and/or environmental factors influence iron homeostasis. 
Table 8 Logistic regression analysis of risk factors associated with elevated transferrin saturation $\geq 50 \%$
Logit-value $(\alpha)$ in this model is -3.586 .

\begin{tabular}{lllll}
\hline Independent variable & $\beta$ & OR Exp $(\beta)$ & $95 \%$ CI & P-value \\
\hline HFE genotype & & & & 0.0001 \\
C282Y/C282Y & 4.456 & 86.1 & $21.6-343.5$ & 0.0001 \\
C282Y/H63D & 1.977 & 7.2 & $2.6-19.9$ & 0.0001 \\
H63D/H63D & 1.700 & 5.5 & $2.0-14.9$ & 0.001 \\
H63D/S65C & 0.498 & 1.6 & $0.2-14.6$ & 0.7 \\
C282Y/wt & 1.186 & 3.3 & $1.4-7.9$ & 0.01 \\
H63D/wt & 0.968 & 2.6 & $1.2-6.0$ & 0.02 \\
S65C/wt & -0.177 & 0.8 & $0.2-4.2$ & 0.8 \\
Alcohol (drinks/week) & & & & 0.07 \\
$6-15$ & 0.095 & 1.1 & $0.7-1.8$ & 0.7 \\
$16-21$ & 0.578 & 1.8 & $0.94-3.4$ & 0.07 \\
$>21$ & 0.862 & 2.4 & $1.1-5.1$ & 0.03 \\
Egg (no./week) & & & & $0.2-1.04$ \\
$>4$ & -0.772 & 0.5 & & 0.06 \\
\hline
\end{tabular}

C282Y homozygous or C282Y/H63D compound heterozygous individuals have an excess dietary iron absorption and may over time develop iron-overload-associated organ damage. However, both the phenotypic penetrance and the expressivity of $H F E$ hemochromatosis are incomplete and several homozygotes and compound heterozygotes do not develop clinical iron overload disease [12, 18]. Modifier genes and/or environmental factors may cause this variability in penetrance.
We observed an age-associated increase in high serum ferritin values $\geq 300 \mu \mathrm{g} / \mathrm{l}$, although there was no significant increase in median serum ferritin levels (Table 3). In H63D heterozygotes, the percent of men with elevated serum ferritin rose significantly more with age than in $\mathrm{wt} / \mathrm{wt}$ homozygotes $\left(\chi^{2}\right.$ test, $\left.\mathrm{p}=0.004\right)$, stressing the impact of H63D on body iron status.

Age-related increase in high serum ferritin values have been reported in other Danish studies [16, 19] and may be
Table 9 Logistic regression analysis of risk factors associated with elevated serum ferritin $\geq 300 \mu \mathrm{g} / \mathrm{L}$

Logit-value $(\alpha)$ in this model is $-2.66$

\begin{tabular}{|c|c|c|c|c|}
\hline Independent variable & $\beta$ & OR $\operatorname{Exp}(\beta)$ & $95 \% \mathrm{CI}$ & P-value \\
\hline$H F E$ genotype & & & & 0.0001 \\
\hline $\mathrm{C} 282 \mathrm{Y} / \mathrm{C} 282 \mathrm{Y}$ & 4.189 & 66.0 & $10.7-404.9$ & 0.0001 \\
\hline $\mathrm{C} 282 \mathrm{Y} / \mathrm{H} 63 \mathrm{D}$ & 1.209 & 3.3 & $1.6-7.1$ & 0.002 \\
\hline H63D/H63D & 0.682 & 2.0 & $0.9-4.2$ & 0.08 \\
\hline $\mathrm{H} 63 \mathrm{D} / \mathrm{S} 65 \mathrm{C}$ & -0.825 & 0.4 & $0.05-3.7$ & 0.5 \\
\hline $\mathrm{C} 282 \mathrm{Y} / \mathrm{wt}$ & -0.308 & 0.7 & $0.4-1.4$ & 0.4 \\
\hline $\mathrm{H} 63 \mathrm{D} / \mathrm{wt}$ & 0.084 & 1.1 & $0.7-1.8$ & 0.8 \\
\hline $\mathrm{S} 65 \mathrm{C} / \mathrm{wt}$ & 0.231 & 1.3 & $0.5-2.9$ & 0.6 \\
\hline Age (years) & & & & 0.03 \\
\hline $39-45$ & 0.585 & 1.8 & $1.03-3.1$ & 0.04 \\
\hline $46-53$ & 0.680 & 2.0 & $1.2-3.3$ & 0.01 \\
\hline Blood donation last 2 years & & & & 0.0001 \\
\hline 0 & -0.0605 & 0.5 & $0.3-0.96$ & 0.04 \\
\hline $1-4$ & -2.032 & 0.1 & $0.04-0.4$ & 0.001 \\
\hline$>4$ & -3.450 & 0.03 & $0.004-0.3$ & 0.001 \\
\hline Alcohol (drinks/week) & & & & 0.0001 \\
\hline $6-15$ & 0.271 & 1.3 & $0.9-2.0$ & 0.20 \\
\hline $16-21$ & 0.777 & 2.2 & $1.2-3.8$ & 0.006 \\
\hline$>21$ & 1.453 & 4.3 & $2.2-8.2$ & 0.0001 \\
\hline \multicolumn{5}{|l|}{ Egg (no./week) } \\
\hline$>4$ & -0.716 & 0.5 & $0.3-0.95$ & 0.04 \\
\hline
\end{tabular}


due to genetic modifiers of iron absorption and/or changes in dietary habits with increased meat [20] and alcohol consumption (www.sst.dk) A similar age dependent effect was not observed for transferrin saturation.

Danish men have a dietary iron intake of median $10.9 \mathrm{mg}$ /day (10-90 percentile 7.2-15.3) [20] with a bioavailability of $15-20 \%$. Cook [21] reported that iron fortification in foods could increase the phenotypic penetrance of hemochromatosis. In Denmark, food iron fortification was stopped in 1987.

The Danish Health Authorities recommended a maximum alcohol intake for men of 21 drinks/week corresponding to $252 \mathrm{~g}$ ethanol/week (www.sst.dk). High alcohol consumption (>21 drinks/week) was associated with elevated serum iron. Among Danish men 45-66 years of age, 20\% consume more than 21 drinks per week (www.sst.dk). However, the increase in serum iron was not high enough to elevate transferrin saturation. Likewise, high alcohol consumption was associated with elevated serum ferritin (Table 4). The positive association between alcohol intake and serum ferritin has been observed in previous Danish surveys [22]. The mechanisms by which alcohol increase serum ferritin are not completely understood, but alcohol can induce hepatocellular injury, suppress erythropoiesis, reduce erythrocyte survival [23] enhance iron absorption and possibly also ferritin synthesis [24], all of which contribute to elevated ferritin. Alltogether, alcohol promotes and accelerates the phenotypic penetrance of $H F E$ variants and the expressivity with development of hepatic damage $[25,26]$.

Donation of blood has a profound impact on iron status [16, 27-29]. Among Danish men, 28\% are blood donors [27]. With an increasing number of blood donations, serum ferritin and eventually serum iron and transferrin saturation decrease. Blood donation is clearly an effective way to reduce body iron stores and decrease the phenotypic penetrance and expressivity of the $H F E$ variants. In patients with $H F E$ associated iron overload, phlebotomies are usually performed until serum ferritin reaches a level of $50-100 \mu \mathrm{g} / \mathrm{L}$.

In our adjusted logistic regression analysis, the $H F E$ genotype had the highest impact on iron status markers followed by blood donation, alcohol intake, age, and egg consumption.

Consumption of meat (beef, pork, poultry) has a positive effect on iron status [30, 31] and men with a high meat intake displayed higher serum ferritin compared to those with a low intake. In addition to "the meat factor", which enhances iron absorption, meat contains heme iron, which has a higher bioavailability than non-heme iron. Therefore, high meat consumption may increase the phenotypic penetrance and expressivity of the $H F E$ variants. Danish men consume median $132 \mathrm{~g}$ meat (beef, pork, poultry) per day (10-90 percentile $46-158)$ and $\sim 80 \%$ consume meat on a daily basis [20].
Drinking large quantities of milk inhibits iron absorption in a dose related manner, probably due to the calcium content [32]. Danish men consume median $248 \mathrm{~g}$ milk/day and $\sim 66 \%$ consume milk on a daily basis [20]. Consequently, devoted milk consumption may lower the phenotypic penetrance of the $H F E$ variants. Other studies have shown that regular tea drinking causes a $30 \%$ decrease in iron absorption in hemochromatosis patients [33].

Egg contains sulphides, which can inhibit iron absorption, but appeared to have no effect on iron status even in a quantity of more than four eggs per week. The recommended intake is 3-4 eggs/week. Danish men consume median 2 eggs/week and $\sim 5 \%$ consume more than 7 eggs per week [20].

Multivitamin-multimineral tablets containing 14-20 mg of ferrous iron had no influence on iron status as previously reported in Danish studies [19]. Among Danish men, 30\% use daily vitamin-mineral supplements containing median $14 \mathrm{mg}$ ferrous iron [27]. Obviously, iron absorption from these preparations is very low, probably due to the content of other essential divalent metal ions (zinc, copper, manganese ect.), which compete with iron about the absorption capacity in the gastrointestinal tract [34, 35]. However, inappropriate use of iron tablets on vague indications such as fatigue ect. without an established diagnosis of iron deficiency may promote iron overload in C282Y homozygous individuals [36-39].

Men reporting having peptic ulcers had significantly lower iron status than men without ulcers. Helicobacter pylori infection may induce peptic ulcer, has a negative influence on iron status [40] and may thereby reduce the phenotypic penetrance of HFE variants. In general, pathological blood losses tend to lower the penetrance and expressivity of the $H F E$ variants

In conclusion, the $\mathrm{C} 282 \mathrm{Y}$ variant have a high phenotypic penetrance in Danish men [11]. The expressivity of the C282Y and H63D variants may be promoted by high alcohol and meat consumption and decreased by high milk consumption and blood donation.

Acknowledgements The authors express their gratitude to the staff at the Department of Clinical Biochemistry at Næstved Hospital for their entusiasm at the performance of this study, especially to Chief Physician Arne Bremmelgaard for devoted support and guidance and to Laboratory Technician Gitte Vedel Melsen for excellent technical assistance.

\section{References}

1. Milman N, Pedersen P, Steig T, Byg K-E, Graudal N, Fenger K (2001) Clinically overt hereditary hemochromatosis in Denmark 1948-1985: epidemiology, factors of significance for long-term survival, and causes of death in 179 patients. Ann Hematol 80:737-744 
2. Milman N, Pedersen P (2003) Evidence that the Cys282Tyr mutation of the HFE gene originated from a population in Southern Scandinavia and spread with the Vikings. Clin Genet 64:36-47

3. Milman N (2000) Inheritance of hemochromatosis: family studies. In: Barton JC, Edwards CQ (eds) Hemochromatosis. Genetics, pathophysiology, diagnosis and treatment. Cambrigde University Press, Cambrigde, pp 15-41 ISBN 0521593808

4. Burt MJ, George PM, Upton JD, Collett JA, Frampton CM, Chapman TM, Walmsley TA, Chapman BA (1998) The significance of haemochromatosis gene mutations in the general population: implications for screening. Gut 43:830-836

5. Olynyk JK, Cullen DJ, Aquilia S, Rossi E, Summerville L, Powell LW (1999) A population-based study of the clinical expression of the hemochromatosis gene. $\mathrm{N}$ Engl J Med 341:718-724

6. McDonnell SM, Hover A, Gloe D, Ou CY, Cogswell ME, Grummer-Strawn L (1999) Population-based screening for hemochromatosis using phenotypic and DNA testing among employees of health maintenance organizations in Springfield, Missouri. Am J Med 107:30-37

7. McLaren GD, McLaren CE, Adams PC, Barton JC, Reboussin DM, Gordeuk VR, Acton RT, Harris EL, Speechley MR, Sholinsky P, Dawkins FW, Snively BM, Vogt TM, Eckfeldt JH, for the Hemochromatosis and Iron Overload Screen (HEIRS) Study Research Investigators (2008) Clinical manifestations of hemochromatosis in HFE C282Y Homozygotes identified by screening. Can J Gastroenterol 22:923-930

8. Phatak PD, Ryan DH, Cappuccio J, Oakes D, Braggins C, Provenzano K, Eberly S, Sham RL (2002) Prevalence and penetrance of HFE mutations in 4865 unselected primary care patients. Blood Cells Mol Dis 29:41-47

9. Jackson HA, Carter K, Darke C, Guttridge MG, Ravine D, Hutton RD, Napier JA, Worwood M (2001) HFE mutations, iron deficiency and overload in 10, 500 blood donors. Br J Haematol 114:474-484

10. Beutler E, Felitti VJ, Koziol JA, Ho NJ, Gelbart T (2002) Penetrance of $845 \mathrm{G}$ A (C282Y) HFE hereditary haemochromatosis mutation in the USA. Lancet 359:211-218

11. Pedersen P, Milman N. Genetic screening for HFE hemochromatosis in 6,020 Danish men: penetrance of C282Y, H63D, and S65C variants. Ann Hematol 2009; doi:10.1007/s00277-0080679-1

12. Allen KJ, Gurrin LC, Osborne NJ, Delatycki MB, Nicoll AJ, McLaren CE, Bahlo M, Nisselle AE, Vulpe CD, Anderson GJ, Southey MC, Giles GG, English DR, Hopper JL, Olynyk JK, Powell LW, Gertig DM (2008) Iron overload related disease in HFE hereditary hemochromatosis. N Engl J Med 358:221-230

13. Elsass P, Pedersen P, Husum K, Milman N (2008) Assessment of the psychological effects of genetic screening of hereditary hemochromatosis. Ann Hematol 87:397-404

14. Pedersen P, Melsen GV, Milman N (2008) Frequencies of the haemochromatosis (HFE) gene variants C828Y, H63D and S65C in 6, 020 ethnic Danish men. Ann Hematol 87:735-740

15. Milman N (1991) Iron status markers in hereditary haemochromatosis: distinction between individuals being homozygous and heterozygous for the haemochromatosis allele. Eur J Haematol 47:292-298

16. Milman N (1996) Serum ferritin in Danes: studies of iron status from infancy to old age, during blood donation and pregnancy. Int J Hematol 63:103-135

17. Milman N, Clausen J, Byg K-E (1998) Iron status in 268 Danish women aged 18-30 years: influence of menstruation, contraceptive method, and iron supplementation. Ann Hematol 77:13-19

18. Andersen RV, Tybjærg-Hansen A, Appleyard M, Birgens H, Nordestgaard BG (2004) Hemochromatosis mutations in the general population: iron overload progression rate. Blood 103:2914-2919

19. Milman N, Byg K-E, Ovesen L, Kirchhoff M, Jürgensen KS (2002) Iron status in Danish men 1984-94: a cohort comparison of changes in iron stores and the prevalence of iron deficiency and iron overload. Eur J Haematol 68:332-340

20. Lyhne N, Christensen T, Groth MV, Fagt S, Biltoft-jensen A, Hartkoop H, et al. Danskernes Kostvaner 2000-2002. Hovedresultater (Danish Nutrition Habits 2000-2002. Main results) DFVF Publication no. 11. ISBN 87-988795-5-3. Silkeborg 2005

21. Cook (2000) Hemochromatosis: effect of iron fortification of foods. In: Barton JC, Edwards CQ (eds) Hemochromatosis: genetics, pathophysiology diagnosis and treatment. Cambridge University Press, Cambridge, UK, pp 535-543

22. Milman N, Kirchhoff M (1996) Relationship between serum ferritin, alcohol intake, and social status in 2235 Danish men and women. Ann Hematol 72:145-151

23. Baynes RD (2000) Interaction of alcohol, iron and hemochromatosis. In: Barton JC, Edwards CQ (eds) Hemochromatosis. Genetics, pathophysiology, diagnosis And treatment. Cambrigde University Press, Cambrigde, pp 468-474 ISBN 0521593808

24. Moirand R, Lescoat G, Delamaire D, Lauvin L, Campion JP, Deugnier Y, Brissot P (1991) Increase in glycosylated and nonglycosylated serum ferritin in chronic alcoholism and their evolution during alcohol withdrawal. Alcohol Clin Exp Res 15:963-969

25. Loreal O, Deugnier Y, Moirand R, Lauvin L, Guyader D, Jouanolle H, Turlin B, Lescoat G, Brissot P (1992) Liver fibrosis in genetic hemochromatosis. Respective roles of iron and noniron-related factors in 127 homozygous patients. J Hepatol $16: 122-127$

26. Brissot P. Clinical spectrum of hepatic disease in hemochromatosis. In Barton JC, Edwards CQ (eds). Hemochromatosis. Genetics, pathophysiology, diagnosis And treatment. Cambrigde. Cambrigde University Press ISBN 0521 593808: p 250-257

27. Milman N, Ovesen L, Byg K-E, Graudal N (1999) Iron status in Danes updated 1994. I: prevalence of iron deficiency and iron overload in 1332 men aged 40-70 years. Influence of blood donation, alcohol intake, and iron supplementation. Ann Hematol 78:393-400

28. Milman N, Søndergaard M (1984) Iron stores in male blood donors: evaluation by serum ferritin. Transfusion 24:464-468

29. Milman N, Kirchhoff M (1991) The influence of blood donation on iron stores assessed by serum ferritin and haemoglobin in a population survey of 1433 Danish males. Eur J Haematol 47:134-149

30. Leggett BA, Halliday JW, Brown NN, Bryant S, Powell LW (1990) Prevalence of haemochromatosis amongst asymptomatic Australians. Br J Haematol 74:525-530

31. Bergström E, Hernell O, Lönnerdal B, Persson LA (1995) Sex differences in iron stores of adolescents: what is normal? J Pediatr Gastroenterol Nutr 20:215-224

32. Barton JC, Conrad ME, Parmley RT (1983) Calcium inhibition of inorganic iron absorption in rats. Gastroenterology 84:90-101

33. Kaltwasser JP, Werner E, Schalk K, Hansen C, Gottschalk R, Seidl C (1998) Clinical trial on the effect of regular tea drinking on iron accumulation in genetic haemochromatosis. Gut 43:699-704

34. Rossander-Hultén L, Brune M, Sandström B, Lönnerdal B, Hallberg L (1991) Competitive inhibition of iron absorption by manganese and zinc in humans. Am J Clin Nutr 54:152-156

35. O'Brien KO, Zavaleta N, Caulfield LE, Wen J, Abrams SA (2000) Prenatal iron supplements impair zinc absorption in pregnant Peruvian women. J Nutr 130:2251-2255

36. Grønbæk KE, Milman N, Skødt V (1995) Preclinical hereditary hemochromatosis - is there an indication for preventive screening? Ugeskr Laeger 157:4249-4250

37. Bell H, Berg JP, Undlien DE, Distante S, Raknerud N, Heier HE, Try K, Thomassen Y, Haug E, Raha-Chowdhury R, Thorsby E 
(2000) The clinical expression of hemochromatosis in Oslo, Norway. Excessive oral iron intake may lead to secondary hemochromatosis even in $H F E \mathrm{C} 282 \mathrm{Y}$ mutation negative subjects. Scand J Gastroenterol 35:1301-1307

38. Hennigar GR, Greene WB, Walker EM, de Saussure C (1979) Hemochromatosis caused by excessive vitamin iron intake. Am J Pathol 96:611-623
39. Perez RF, Amigo EA, Gonzalez CP (1998) Hemochromatosis presenting as acute liver failure after iron supplementation. N Engl J Med 339:269-270

40. Milman N, Rosenstock S, Andersen L, Jørgensen T, Bonnevie O (1998) Serum ferritin, hemoglobin, and Helicobacter pylori infection: a seroepidemiological survey comprising 2754 Danish adults. Gastroenterology 115:268-274 